\title{
Social and economic forms of beach managing in Croatia
}

\author{
S. Favro ${ }^{1}$, M. Kovačić ${ }^{2} \&$ M. Perišić ${ }^{3}$ \\ ${ }^{1}$ Adriatic Expert, Croatia \\ ${ }^{2}$ Faculty of Maritime Studies, University of Rijeka, Croatia \\ ${ }^{3}$ Plovput, d.o.o. Split, Croatia
}

\begin{abstract}
Beaches are natural resources that significantly enrich the tourist offer of countries gifted by nature near the sea. Apart from economic significance, beaches also have recreational importance, and are, therefore, vulnerable to various adverse influences that result from natural changes or manmade activities. Beach management is mainly entrusted to authorities and in Croatia to public administration. As beaches are public good, they may be subject to concessions and concession approvals. Beach management in Croatia is defined by numerous institutional provisions with the aim to protect beaches and their sustainable use. The authors in this paper explain general knowledge on beaches, integrated beach management and models of beach management in Croatia. They analyze the existing system of beach management, and propose improvements that are socially responsible and economically efficient. Proposed improvements are applicable to other countries that face problems related to public administration and its management of public good, i.e. beaches.
\end{abstract}

Keywords: public and common resources, beach managing, types of management, concessions, concession approvals.

\section{Introduction}

Beaches are a major source of income in the world, and in the last few years there is a growing interest in the possibility to use their recreational and economic potential in Croatia, too. According to its total coast length of $5835.2 \mathrm{~km}$ (islands and mainland), Croatia is far ahead of all Adriatic countries (74\%), it has indented coast (with the coefficient of 11.10 is the second in the 
world), and has numerous islands $(1,246)$, which makes it, along with Greece, the first on the Mediterranean.

How many beaches Croatia can boast of, is still unknown. It is assumed that there are approximately 2,000 beaches, thereby taking into account 7 Adriatic counties, of which there are 376 beaches only in the Primorsko-Goranska County for which individual characteristics (area, type, etc.) have been registered. It is a project [12] that carried out County Department of Development, Regional Planning and Environmental Protection in the Primorsko-Goranska County that in cooperation with external institutions has made a cartographic representation called: Sea beaches in the area of the Primorsko-Goranska County. A special question is what such a unique beach cadastre (database) would provide to Croatia. It is logical to conclude that resource management is possible when there are pieces of information about them and their characteristics. A data base on beaches would enable progress in beach protection but also in social and economic use.

\section{Defining the issue}

In order to effectively manage beaches, it is important to understand what beaches are, how laws in Croatia define and classify beaches, what their importance as a resource is, and how to evaluate them.

\subsection{Theoretical approach}

A beach can be defined as a zone of unconsolidated material (for example sand, gravel, clay or their mixture) that extends along the shoreline from the edge of the beach land that can be a slope, dune or a seawall to the sea depth where there isn't any significant movement of sediments [10]. Beach types can be defined by taking into account a wide range of physical, natural and anthropogenic determinants which, among other things, may include physical oceanography, the composition of phytogene sediment, colors, form, stability, the preservation degree of habitats and species, the level of naturalness, the level of beach utilization and its surrounding, and the alike [9].

Beaches should be conceived as multidimensional environmental systems that are nested within larger coastal systems and comprised of interacting natural, socio-cultural and management systems.

A beach is a part of the sea or freshwater coast arranged for bathing. A beach can be completely natural, but it can also be artificially constructed coastal area adapted to facilitate swimming and refreshment to people during summer months. Arranged beaches are equipped with amenities such as restaurants, bars, toilets, showers, and others. Modern beaches are also equipped with facilities for sport and recreation such as beach volleyball courts, water slides or tennis courts. There is usually a possibility on such beaches to rent a jet ski, gondola, pedals, equipment and a speedboat for water skiing, surfboards, diving equipment, and other things. 
Today, safety is one of the elements that have a special significance in tourism. That is way more and more beaches have lifeguards made of boys and girls who have finished lifeguard and first aid courses. As beaches are considered a safe recreational environment in which various society members can enjoy, the beaches started to be considered a highly valuable social-economic national resource that requires an effective management. The beaches represent the main focus of global tourism [2], they have become icons of modern tourism, and are generally considered the main factor of the tourism market. The desirability of such recreational areas as well as public awareness on health and safety issues is on the increase by extending the time for recreation, and expectations in terms of quality and choice are created. As a result, the need to create an effective scheme for classification, evaluation and management of the beach area arose.

In many countries, local government has the power to adopt subordinate acts regarding public beaches and beach management [3]. Nevertheless, most of the provisions regarding beach management are included in broader acts on coastal area management or some sectoral provisions [6]. Of special interest for beach management is legislation relating to bathing water quality, beach safety, feeding, coastal protection, beach access and protection of key ecosystems such as sand.

There are a very small number of papers devoted to beaches in Croatian literature. Mainly there are projects (COAST), studies, guidelines, and others [7].

According to Anic [1], the beach is "the area along the shore, river or lake, especially adapted for swimming". Beaches along the rivers and lakes are distinguished from sea beaches primarily by the fact that they may be in the property regime which is contrary to the beaches along the seashore that fall within the maritime domain. Maritime domain is a common good which means that it is not and cannot be in a regime of ownership and belongs to goods outside commerce, res extra commercial [5].

Furthermore, a beach is defined as a complex system of uniting mainland and the sea, a valuable natural habitat, and a significant area to which specific social and economic conditions are related. It is a highly valuable resource in terms of natural, social and recreational potential which is jeopardized by various potentially harmful effects as a result of numerous, natural and other forces, especially the human ones.

Taking into account recreational characteristics of beaches, in the Physical Planning and Construction Act [14] in Article 53 beaches are designated as regulated and natural beaches. It also defines that:

- a well-maintained beach, inside or outside the village is controlled and accessible to all on equal terms with the land and sea including persons with reduced mobility, largely regulated natural and modified characteristics, as well as infrastructure and content (showers, cabins and sanitary) arranged land area directly connected to the sea, marked and protected from the sea

- natural sea beach, inside or outside the village is controlled and accessible from land and/or sea with unequipped infrastructure, the current brand of preserved natural features. 


\subsection{An overview of past research in Croatia}

A survey which included islands, islets and rocks, with an emphasis on small, occasionally inhabited and uninhabited islands and islets, was carried out in Croatia in 2007 [12]. A systematic beach research to determine their actual or approximate number hasn't been carried out yet. Although a number of individual researches, studies and projects, which point at the need of unification, have been carried out. There are several reasons, such as the disunion in the jurisdiction of Croatian coastal zone management and the lack of financial means. In fact, this research requires certain financial assets and involvement of institutions and experts. Currently, there isn't a comprehensive beach managing strategy in Croatia. There are some initiatives for the evaluation of biodiversity of beach habitats as well as initiatives to evaluate recreational and safety aspects of beach areas. However, a unique beach management system, that would include an overall evaluation of natural resources and recreational potential of that level that should be respected on the beach in order to preserve and improve these resources, still doesn't exist. The only initiative that is in force and that partially meets these criteria is the Blue Flag programme, although it is primarily oriented towards beaches as recreational resources, and with the regard to the above mentioned, it is mainly focused on urban and resort beaches. Key initiatives, programmes and studies focused on some aspects of beach management include:

- Water quality monitoring programme and creation of a database on bathing water quality,

- Creation of beach profiles which will be used to make assessments on bathing water quality determined on the basis of criteria defined by the Regulation on Sea bathing water quality [19]

- Creation of cartographic representation project of beaches in PrimorskoGoranska County and Dubrovnik-Neretva County in accordance with the Regulation on Quality Standards at Sea Beaches [18]

- Some initiatives of evaluating natural and recreational beach resources such as researches within COAST project or analysis of beaches by the BARE methodology

- Individual specific studies for the management of selected beaches, and

- Numerous initiatives regarding practical maintenance, primarily beach cleanness.

Croatia, as a contracting party to the Barcelona Convention - Convention for the Protection of the Mediterranean Sea against Pollution, is one of the first countries that have started to implement a systematic approach for quality water monitoring. In accordance with the above mentioned, counties pursuant to the Regulation on Sea bathing water quality [20] has ensured the analysis of water quality by providing funds in the budget and by creating adequate maps. The implementation has been entrusted to Institutes for Public Health, and the coordination to National Environment Agency in Rijeka. 
For the implementation of this Regulation, County Institute for Development, Physical Planning and Environment Protection has created corresponding maps on topographic maps of 1:25,000 scales in the publication "Sea Beaches in the Area of Primorsko-Goranska County", with the following data:

- Location and name of the beach

- Sea beach boundary line

- Discharge and the amount of waste water

- Submarine Discharges

- Waste water treatment systems

- costal springs, submarine springs, freshwater inflows

- Sampling points.

Sampling points of bathing water on a sea beach shall be as follows:

- $\quad$ on a sandy or pebbly beach, one sampling point every $100 \mathrm{~m}$ of length

- $\quad$ on other beaches, one sampling point every $200 \mathrm{~m}$ of length

- $\quad$ one sampling point at each sea mouth of watercourses, costal spring and submarine spring.

Beach boundary lines and other relevant data are grouped by municipalities and cities, and reported on all Croatian state maps (HDK) of 1:5,000 scale.

The Regulation also defines time framework for carrying out the analysis, and that is from the $1^{\text {st }}$ May until the $30^{\text {th }}$ September, i.e. till the end of the swimming season. Bathing water samples shall be taken every 15 days in the way prescribed by the Regulation. Years of bathing water quality monitoring have resulted in creating a Data Base that is based on:

- Environmental Protection Act [13],

- Physical Planning and Construction Act [14],

- Strategy of sustainable Development of Croatia (30/09) and the Directive 2006/07/EZ of the European Parliament and the Council on the management of bathing water [23],

- the Guidelines on the quality of bathing waters of the Mediterranean Action Plan (MAP),

- the Guidelines on the safety of water intended for swimming and recreation of the World Health Organization (WHO), and

- Regulation on Bathing Water Quality [19].

The data base for input, processing and valorization of the monitoring results, as well as for timely public information on sea bathing water quality along the Adriatic coast has been established by The Ministry of Environmental Protection, Physical Planning and Construction. MEPPPC has developed a bilingual web browser in order to inform the public. The browser enables the view of collected data from the sampling locations, real time sea water quality evaluations during the season, information on hydrological and meteorological conditions on the day of sampling, and information about sudden and short-term pollution. Sea bathing water quality evaluations in the browser are visible on Google maps backgrounds, and besides the seawater quality it is also possible to 
obtain information about the beach facilities, the main features, see photos of beaches, provide comments for each beach, and propose new sampling locations. The report of the authorized Ministry for 2011 included 906 measuring points located on so called active beaches.

\section{Research methodology}

An overview of legal regulation that is in function of beach management and the analysis of existing models of beach management in Croatia are given in this chapter. An overview of ecological program of beach protection, Blue Flag and the selection of the most beautiful beaches within the promotional action Tourist Flower are also given in this paper.

\subsection{Legal guidelines of beach managing and beach classification in Croatia}

Beach managing in Croatia can be seen from the aspect of sea protection, ecological aspect and the jurisdiction aspect that in accordance with Maritime Domain and Seaports Act [16] and the Concessions Act [17] has been given to regional government (counties), and local government (cities/municipalities).

Analyzing beaches in the context of their use, Regulation on the Procedure for Granting Concessions on the Maritime Domain [20] defines beaches as:

- Organized public beaches - beaches intended for a larger number of tourist facilities and citizens.

- Organized special beaches - beaches that form a technical and technological entity of one accommodation facility in terms of the Catering Act.

- Natural beaches - beaches where no interventions were made in terms of regulations that regulate spatial planning and constructing and that must not be fenced off from the mainland.

It should be noted that pursuant to the Regulation, organized public and special beaches, when subject to concession, may be in the status of open beaches, and the beach can be fenced but doesn't require payment of tickets, or the beach may still be fenced but the access to the beach should be paid (for example City beach in Crikvenica, some nudist beach camps, etc.). Law provides the possibility to limit and charge admission to regulated beaches. Croatian regulations consider rocky shores and artificial beach areas (such as a concrete coast) regulated beach types.

For other areas adequate terms are bathing and/or stony (rocky) coast. The starting point for this classification can be found in the Regulations on beach types and conditions they must meet [22]. According to the type, beaches were divided on natural and arranged in 1995. According to those Regulations, arranged beaches are equipped with toilets, showers, cabins, fenced from the sea side and accessible to all users equally. Natural beaches are unarranged areas that directly connect the sea with the land and that is accessible to everybody. 


\subsection{Models of beach managing in Croatia}

In accordance with the law, the state has entrusted beach managing in Croatia to regional and local government, and has given the possibility to give concessions and concession approvals. In that way, beach managing has the function of retaining or improving the beach as a recreational resource, as an instrument of coast protection, and a very important function of beach management. Within that context, good beach management, as a continuous process, has to ensure protection of beach resources and maintenance of beaches within available financial means. In Croatia, regional government gives beach concessions, and in come counties that authorization has local government.

A concession is a right by which a part of maritime domain is partially or fully excluded from general use and is given for special use or economic exploitation to physical and legal persons registered for operating a business. Acts that regulate this complex area are: Maritime Domain and Seaports Act, [16] Regulation on the Procedure for Granting Concessions on the Maritime Domain [20], and specially the Concessions Act [17]. When making a beach concession, special obligations of the concessionaire relate to:

- Maintenance of existing utility infrastructure on the beach location

- Organization of secure services if possible on all beaches with a large number of swimmers

- The safety of navigation and swimmers provided by conditions of positive regulations from conditions for performing activities on maritime domain

- Posting information boards with the name of the beach and the concessionaire

- Maintaining secure beach accesses, and eventually accesses for persons with disabilities,

- Fencing sea borders of the beach by buoys at the sea,

- Maintaining daily cleanliness and garbage disposal, daily grasping, signposting, cabin posting, and maintenance of playgrounds and sandboxes.

A maximum number of chaise lounges and parasols are defined on beaches. Pedals and similar equipment must not be placed in the way to jeopardize swimmers' safety. Their location should be specially defined.

Concession approval shall be given by the Concession Approval Council in the way regulated by Concession-granting Decision on maritime domain [21]. The council acts in towns and municipalities define this subject:

"Concession approval is an act which can be issued to physical and legal persons registered for business operations, for performing activities on maritime domain that neither exclude nor limit general use of maritime domain."

In the case, when several requests for performing the same activity on the same location are delivered to the Council, the Council will issue a concession approval to the applicant whose application is received before others, whose application is complete and possible. If more applications for performing the same activity on the same location are received at the same time, the concession 
approval will be issued to the applicant who requests to perform more activities on the same area of maritime domain if the application is complete and possible. The Council will reject the request for a concession approval of the applicant who hasn't made the payment of concession approval fee for the past year. In cities and municipalities, issuing concession approvals is defined by the Annual Maritime Domain Management Plan. Activities that can be carried arise from the Integral List of Activities on Maritime Domain and they are divided in few groups:

- equipment rental,

- catering and trading,

- commercial and recreational attractions,

- transportation of passengers and cargo, charter,

- technical work (cleaning the sea, cranes for lifting vessels, etc.),

- training swimming, boating and diving,

- organization of diving and other excursions.

\subsection{Environmental plan for beach Protection}

The Blue Flag for beaches and marinas is an international environmental program for sea and coastal zone protection, whose aim is sustainable management of the sea and coastal zone. National coordinator and the Blue Project program leader in the Republic of Croatia is the environmental association Lijepa naša [11].

In December 2000, EU Commission adopted the communication for the European Parliament and the Council regarding the development of new policy on bathing water quality, and it launched extensive consultations with all interested and involved parties. The main outcome of these consultations was general support for the development of the new Directive based on the latest scientific evidences and by paying special attention to the participation of general public.

The Directive commends that the public has to receive proper and in time pieces of information on monitoring bathing water quality and on measures regarding risk reduction in order to prevent health-related risks, especially regarding a predictable short-term pollution or unusual situations. New technology that enables efficient and appropriate informing the public on bathing waters in the Community should be used.

The Directive also imposes regulations for monitoring and classification of bathing water quality, as well as for informing the public on bathing water quality. In the table 1 are listed beaches that have met standards due to which the Blue Flag for 2012 has been given to them.

In 2012, 124 Blue Flags were awarded in Croatia out of which 106 were to beaches that can be at the sea but also at rivers or lakes. There are 5 beaches with the Blue Flag in Zagreb. Rijeka's beaches Kostanj and Ploče were awarded the Blue Flag on the $5^{\text {th }}$ June 2012. The remaining 18 Blue Flags were assigned to marinas in Poreč, Pula, Punat, Zadar, Biograd na moru, Tribunj, Primošten, Rogoznica, and Opatija (table 1). 
Table 1: $\quad$ The number of blue flags in Croatia from 1998 until 2012.

\begin{tabular}{|c|c|}
\hline Year & The number of flags \\
\hline 1998 & 1 \\
\hline 1999 & 13 \\
\hline 2000 & 22 \\
\hline 2001 & 29 \\
\hline 2002 & 48 \\
\hline 2003 & 73 \\
\hline 2004 & 98 \\
\hline 2005 & 111 \\
\hline 2006 & 121 \\
\hline 2008 & 146 \\
\hline 2009 & 135 \\
\hline 2010 & 135 \\
\hline 2011 & 135 \\
\hline 2012 & 124 \\
\hline
\end{tabular}

Source: made by the author

The Tourism Flower - Quality for Croatia is an action of Croatian Radio and Television and the Chamber of Commerce that in 2012 carried out the Institute for Social Research "Ivo Pilar" in Zagreb. Within this action the Best Beach in various categories (urban, rural, natural, and others) is selected for the $7^{\text {th }}$ year in a row. The Committee formed of representatives from relevant sectors takes part in the selection of the beach. Research on the quality of selected tourist destination in 2012 included 97 places, out of which 59 were in Coastal and 38 in Continental Croatia.

Places that were included in the research were selected in accordance with the following criteria: the number of overnight stays, the number of residents and the administrative status. The committee visits selected destinations secretly every year in July and August, and after the research and data analysis, publishes a ranking list of destinations that is the base for the Tourism Flower Award. The aim of the action is to raise the awareness of citizens and all other stakeholders in that place on the importance of tourism in raising the overall living quality in the local community.

\section{Results and recommendations for improving the beach management system}

A concession system in Croatia has a development and protective role for the local community, region and the country as a whole [3]. However, such system has to be transparent and concession-granting procedure efficient. Decisions have to be made within a reasonable period without unnecessary administration and hierarchical levels. Public administration has to stimulate the development and concessions as legal and economic mechanism may greatly contribute to it so they should be seen from that aspect. In that sense, it is necessary that the new Maritime Domain and Seaports Act, which is in preparation, implements the 
possibility to gain a concession at request, that is already highlighted in the new Concession Act. Such practice also exists in other countries, and the purpose is to enable business subjects (especially hotels, resorts, camps but also local government) running a business without being disturbed as well as investment protection in the area of one technical and technological unit. A question on duration of beach concession also rises. International practice recognizes a period of 7-10 years when there are no investments, and more years when it comes to major investments. Furthermore, it should be noted that the administrative division of Croatia into counties defines beach management authority on a smaller geographical area. Therefore, inter-county beach management practices may differ, but in essence they must meet the criteria of integrated coastal zone management, and a uniform application.

Valorization of beach resources and beach environment in Croatia still hasn't been systematically solved $[2,4]$. A data base that contains the classification data of beaches is formed on the state level but this data base contains only beaches where the sampling is carried out. Regional administration has different approaches towards this issue. The Primorsko-Goranska County has a beach cadastre, which provides exact data on the type, length and beach structure, and position within a certain location. Split-Dalmacija County, in order to valorize maritime domain, has made a model for the evaluation of maritime domain that includes an overview of activities, ecological and economic valorization and criteria for the valorization of maritime domain. The implementation of the model helps in decision making regarding maritime domain management, especially beaches. Today, most counties in Croatia use geographic information system for data processing. This system is becoming more and more represented among the majority of users, especially among the ones who make decisions because in a simple and acceptable way shows sometimes very abstract data. But a problem of expert and intellectual capacity and their competences may arise. On a local level, management is being carried out in accordance with maritime domain management plans made by cities/municipalities, in the way to issue concession approvals or it is managed by municipal trading companies. In recent years, desire and willingness of the local government to assume responsibility for beach management through the institute of concessions on its administrative area has become visible. It has particularly come into life in Istria County. In that way, local government has an extra motive to directly manage the development of beach resources in accordance with existing spatial plans.

Today, beach management has a much higher meaning, economic, social and ecological, and that is why it should be based on principles of sustainable development [9]. Recommendations for an efficient management are primarily related to the following issues:

- development of intellectual capacities,

- coordination among institutions (national, regional, and local),

- Pro-activity and orientation towards future.

The basic guideline of a good beach management on the local level involves participation of citizens in decision-making regarding the use of public good, as well as partnership between local authorities, civil society organizations and 
private sector. Experiences of some countries and methodological approach in the evaluation of beach area are an additional tool for effective and sustainable beach managing.

\section{Conclusion}

Croatia is a country that has succeeded in preserving its resources and their value although it is time to define in what extent Croatia has at its disposal these resources. An exact data on the total number of beaches (beach cadastre) on Croatian Adriatic coast still doesn't exist. As data gathering is a very complex work, it requires additional funding and involvement of scientists and experts from various fields. It is believed that it won't be an obstacle as this resource is very valuable. Models of commercial use of beaches in Croatia are based on legal solutions that involve granting concessions or concession approval.

The procedure to get a concession approval is easy but the one to give a concession is complex and long. Frequent changes of law and regulations lead to legal uncertainty that should be avoided in the future, and the procedures should be simplified. Croatian beaches with their beauty represent a real fortune that should be protected and wisely used because once a something is destroyed it is hard or even impossible to repair it. That is why scientists and experts should know their role and should do everything possible to preserve this highly valuable resource for future generations.

\section{References}

[1] Anic, V., Croatian Language Dictionary, Third, expanded edition, New Liber, Zagreb 1998. p. 768.

[2] Jovicic, D. and Cara A., The assessment of carrying capacity is crucial tool for managing tourism effects in Tourist destinations. TOURISM. 12, Zagreb 1998, pp. 4-11.

[3] Kovacic, M., Komadina, P., Coastal Zone Management and Sustainable Development, Faculty of Maritime Studies, Tiskara Sušak, Rijeka, 2011.

[4] Kovacic, M. Favro, S., Perisic, M., The Issue of Coastal Zone Management in Croatia, The Issue of Coastal Zone Management in Croatia - Beach Management, Tourism\&Innovation Journal, Year 3, No.1-2, July 2010, ISSN 1855-3303.

[5] Kundih, B., Croatian maritime good in theory and practice, Rijeka 2005.

[6] Markovic, M., Micallef, A., Povh, D. and Williams, AT., Guidelines and priority actions for the sustainable management of beaches, United Nations Development Programme, Split 2010, 240 pp.

[7] Markovic, M., Guide to selected beaches in Croatia, Association for Nature, Environment and Sustainable Development, ed., 2006, Split, Croatia.

[8] Simm, J.D., Beech, N.W. and John S., A Manual for Beach Management, Proceedings of Coastal Conference on Management'95, Putting Policy into 
Practice, Institution of Civil Engineers, Bournemouth, Thomas Telford, UK 1995, pp. 143-162.

[9] Various authors, The Beach Management Manual (Second Edition), CIRIA, 2010.

[10] Williams, A.; Micaleff, A., Beach Management: Principles \& Practice, Earthscan Publications Ltd.., London, UK, 2009.

[11] http://www.lijepa-nasa.hr/plava-zastava

[12] Ministry of the Sea, Maritime and Infrastructure, HHI, The State program for the protection and use of small, sometimes inhabited and uninhabited islands and the surrounding sea, Zagreb, 2007.

[13] Environmental Protection Act (Official Gazette 110/07).

[14] Law on Physical Planning and Construction (Official Gazette 76/07, 38/09, $55 / 11,90 / 11,50 / 12,55 / 12$ ).

[15] Law on Maritime Domain and Seaports Act (NN 158/03, 100/04, 141/06, 38/09).

[16] Law on Concessions (Official Gazette 143/12).

[17] Public institution Department of Development, Regional Planning and Environmental Protection in the Primorsko-Goranska County.

[18] Regulation on standards of water quality at beaches (Official Gazette 33/96).

[19] Regulation on the quality of bathing water (Official Gazette 73/08).

[20] Regulation on the procedure for granting concessions in the maritime domain (Official Gazette 23/04, 101/04, 39/06, 63/08, 125/10 and 83/12).

[21] Regulation on the procedure for granting a concession agreement on the maritime domain (Official Gazette 36/04).

[22] Regulation on the types of beaches and the conditions that must be met (Official Gazette 50/95).

[23] Strategy for Sustainable Development Strategy (Official Gazette 30/09) and 2006/07/EZ Directive of the European Parliament and of the Council concerning the management of bathing water. 